\title{
CHARACTERISTIC OF INTERACTION STIMULANT FACTORS ANALYSIS ON SOCIAL MEDIA INSTAGRAM ACCOUNT @ditjenpajakri
}

\author{
Wuri Arenggoasih \\ Institut Agama Islam Negeri Salatiga, Indonesia \\ rorowuri@iainsalatiga.ac.id \\ Ifadatul Khabibah \\ Institut Agama Islam Negeri Salatiga, Indonesia \\ ifadatulkhabibah1903@gmail.com
}

\begin{abstract}
Consciously or not, the social media era has moved the flow of information to their gadgets. Indonesia has been ranked third as an active user of social media Instagram. So, currently both personally and institutionally it is not unusual to have an Instagram account such as the Republic of Indonesia Directorate General of Taxwith account @ditjenpajakri. Exactly, the beneficiary of the account has become an interactive medium that increases popularity to encourage trust and conversion tax in Indonesia towards the tax-aware generation. Therefore, the purpose of this study is to determine the characteristics of interaction stimulant factors on the @ditjenpajakriaccount with the content analysis method on various components that encourage interaction in 504 posts in 2018. The results of the research reveal that the booster component of the @ditjenpajakriaccount interaction consists of the type of photo/image, the number of likes/love and followers/comments, types of captions, and hashtag.
\end{abstract}

Keywords: Instagram, Social Media, Tax

\begin{abstract}
Abstrak
Secara sadar atau tidak, era media sosial telah memindahkan arus informasi ke gadget masing-masing. Indonesia telah menduduki peringkat ketiga sebagai pengguna aktif salah satu media sosial instagram. Sehingga, saat ini secara personal maupun lembaga bukan hal aneh bila memiliki akun instagram seperti Ditjen Pajak RI dengan akun @ ditjenpajakri. Pemanfaat akun sebagai media interaksi yang meningkatkan popularitas agar mendorong kepercayaan dan konversi perpajakan di Indonesia menuju generasi sadar pajak sangatlah tepat. Olehsebab itu, penelitian ini diharapkan dapat menjawab bagaimana karekteristik akun@ditjenpajakri dengan metode analisis isi pada berbagai komponen yang mendorong interaksi di 504 post tahun 2018. Hasil riset mengungkap bahwa komponen pendorong interaksi Akun@ditjenpajakri terdiri dari jenis foto/ gambar, jumlah like/love dan pengikut/komentar, jenis caption, serta hashtag.
\end{abstract}

Kata kunci: Instagram, Media Sosial, Pajak 


\section{Introduction}

In 2004, it was often said to be a turning point for social media because this year Facebook was born which then rapidly revolutionized the world of communication. Followed by other social media that came up was Instagram in 2010. Even in 2018, Facebook claimed to have 300 million users every day in September while Instagram Stories reached 400 million users in June (Ekasari, 2018). Indonesia apparently has 45 million people who use this social media actively, and is listed as the most Instagram Story creator in the world (Aghni Adi, Ali Hidayat, 2017). Another fact, Indonesia ranked third in the category of active users on Instagram totaling 53 million accounts in January 2018.

A lot of enthusiasts or users of Instagram social media, APJII divides Instagram into 3 types, namely: personal Instagram account, business Instagram account and general or general Instagram account. Personal instragram accounts are accounts owned by Instagram users with the username used is the user name. This account is usually used to share the daily activities of the account owner who has a follower of friends, relatives and even fans. A business instagram account is an account that is used for business activities, such as an online shop or offering services. Instagram also provides a business-specific account, but still most people use a personal Instagram account for business. In fact, Business Instagram accounts have features such as connecting to Facebook Fanpage to facilitate posting photos, analytic features help monitor Instagram visitors weekly traffic and a "call" feature that allows customers to directly contact businesspeople. Finally, a general Instagram account or a general account has a special theme. As an example of an account exploring travel, the content on the account is related to tourist attractions or natural views and has a large or viral viewer. Special themes and many followers are an extraordinary potential for monetization so this account is commonly used to receive endorsers or promotions and 
help flow traffic to the account (Wulandari, 2018).

Many enthusiasts or users of Instagram social media, APJII divides Instagram into 3 types, namely: personal Instagram account, business Instagram account and general Instagram account. Personal instragram accounts are accounts owned by Instagram users with the username used is the user name. This account is usually used to share the daily activities of the account owner who has a follower of friends, relatives and even fans. A business instagram account is an account that is used for business activities, such as an online shop or offering services. Instagram also provides a business-specific account, but still most people use a personal Instagram account for business. In fact, Business Instagram accounts have features such as connecting to Facebook Fanpage to make it easier to post photos, analytic features help to monitoring Instagram visitors weekly traffic and a "call" feature that allows customers to directly contact businessman. Finally, Instagram General Accounts are like travel explore accounts that have content related to tourist attractions or nature view. The success of accounts that have multiple or viral views is an extraordinary potential for monetization. Because, accounts are usually used to receive endorsers or promotions and help stream traffic to the account (Wulandari, 2018).

The era of social media has indeed changed the habits of the communicators, even the term communicant is like living a habit because everyone becomes very ready to act as the sender of the message. At the time of mainstream media such as TV, print and radio had full power over issues that appeared in the community. However, that role is now replaced by social media. For example, currently the fastest and highly anticipated source of Indonesian celebrity gossip is an Instagram account, @1ambeturah. Therefore, it is like an obligation for public figures or institutions to have a social media account, one of which is owned by the Director General of Taxes with the Instagram account @ditjenpajakri. 
The@ditjenpajakri account already has 898 posts, 104 thousand followers and only follows three other accounts, namely the Minister of Finance Sri Mulyani Indrawati with the@smindrawati account, the Ministry of Finance account with the @kemenkeuri account name and the Indonesian President Mr. Joko Widodo with the name @jokowi account. The first upload was posted on October 30, 2016 about the socialization activity "Tax Amnesty in Indonesia" at the Doctor's Candidates Gathering Program of the Doctor of Economics Concentration in Accounting at FIS Trisakti University by the Director General of Taxes Mr. Ken Dwijugiasteadi. The following are the number of posts on the @ ditjenpajakri account per year until Desember 24, 2018:

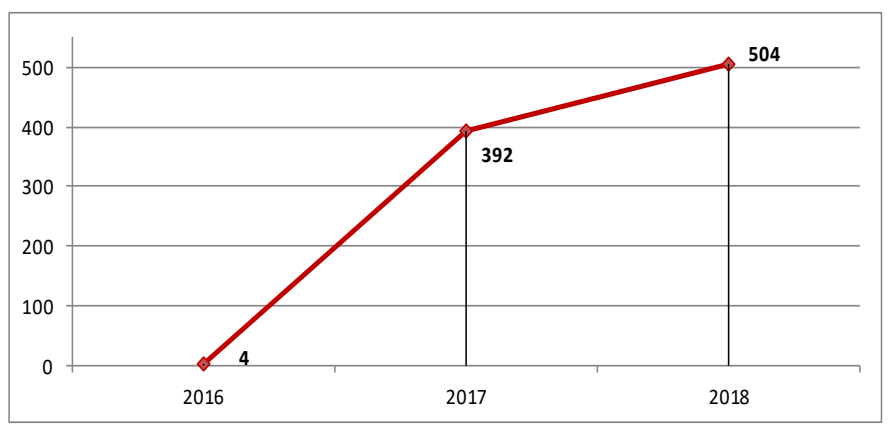

Grafik 1: Jumlah Postingan Pada Akun @ditjenpajakri Per Tahunnya Hingga Tanggal 24 Desember 2018. Source: data diolah dari @ ditjenpajakri

Looking at the chart, the @ditjenpajakri account has seriousness in disseminating information, especially starting in 2017. When calculated on average, the @ditjenpajakri account uploads information almost every day in 2017. Then it increases in 2018 by uploading 1-2 posts per day. Ilham Saputra, a practitioner of social media and digital marketing, believes that social media can be utilized as a brand development through creative content strategies so as to achieve a level of popularity. Furthermore, the brand must also control social media to maintain reputation and 
opinion to be more stable with the aim of interaction and maintain a good relationship with the audience to increase consumer confidence and increase sales conversion (Saputra, 2017).

The use of social media in the millennium era is considered appropriate as an effort to improve awareness of paying taxes. The Directorate General of Tax (DGT) implements a Tax Awareness Inclusion Program that seeks to change the paradigm of Indonesian society. The expected change is the paradigm of being forced to pay taxes into an act of pride after paying taxes because it contributes to the country in the Tax Awareness Generation (Mardlo, 2018).

The conscious of tax generation who are embarrassed if they do not carry out tax obligations. The creation of this generation is a solution to overcome the problems faced by taxes in Indonesia. In 2017, Sri Mulyani as Minister of Finance stated about the low of awareness for paying taxes in Indonesia when compared to the World Bank's standard assessment of a country in 15\% (Quddus, 2018). Indonesia has received only 10.6\% taxes from gross domestic product (GDP) or domestic products in 2016 (Sembiring, 2017). Director General of Tax Ken Dwijugiasteadi explained the reasons from the low awareness people for paying taxes, namely they don't obey the tax laws, lack of trust in the tax authorities and have not become a culture. (more afraid of not having a SIM than not having a TIN so they do not consider tax important), there is no understanding of the benefits of tax returns and the difficulty of tax reporting (Afrianto, 2016). People are more afraid of not having a SIM than a tax ID so they do not consider tax important. Thus, they do not yet have an understanding of the benefits from tax returns and the difficulty of tax reporting (Afrianto, 2016).

Therefore, expecting of the research can explain the characteristics of @ditjenpajakri account as an increase in tax-aware generation by various interaction stimulant factors. There are types of photos/images, number 
of likes/likes and followers/comments, types of captions, and hashtags. Some other research on Instagram account activity Most of them are looking at the characteristics of accounts to support several publications such as the first, What We Instagram: First Analysis of Instagram Photo Content and User Types by Yuheng $\mathrm{Hu}$, et al ( $\mathrm{Hu}$, Manikonda, \& Kambhampati, 2014, p 595-598). Second, a study entitled Instagram Marketing: Salmalina Salleh's Best Malaysian Restaurant Brand Content Analysis found that the growing popularity of photo-based social media would be very helpful in promoting restaurants (Salleh, Hashim, \& Murphy, 2015). Third, dissecting Instagram: Edwin Adrianta Surijah's Bali Social Media Contents Analysis, reveals various types of uploaded images chosen by user preferences or follows an account on natural, simple, and informational image choices (Surijah, Kirana, Wahyuni, Yudi, \& Astini, 2017, pp. 1-17).

\section{Theoretical Framework and Development}

\section{The Indonesian Directorate General of Tax as a planned brand}

As previously stated, if the Directorate General of Taxation of the Republic of Indonesia through the @ditjenpajakri account is considered a brand, it must control social media to keep reputation and opinion stable with the aim of interaction and maintain a good relationship with the audience to increase consumer confidence and increase tax payments. Why is likened to a brand? What is the importance of a brand? Brand or brand is not something that can be allowed to develop or change by chance. A brand is a construction that is created, stimulated and applied by an organization by seeking consumer/customer experience that will induce behavior that is beneficial to the organization. Thus, for the development of a brand requires preparation and planning (Gelder, 2005, p. 1).

The stages required by the brand in preparation and planning consist of business strategy, brand expression, the marketing mix, brand 
perception, brand recognition and consumer behavior (Gelder, 2005, pp. 1-4). Business strategy is planning by compiling a direct and convincing brand strategy. In this first stage, the brand is designed to persuade consumers to exhibit certain behaviors. The success of the strategy is proven if consumers actually buy, use goods (more often), pay higher prices or contribute more (Gelder, 2005, pp. 1-2). So, the tax payers are becoming more tax conscious. In the second stage has the task of changing business strategy into brand expression. This means getting a complete view of all elements of brand expression, then choosing which one to use and emphasize in brand manifestations especially including the full experience consumers have of the brand (Gelder, 2005, p. 2). In the third stage is the marketing mix which aims to translate brand expression into actual products or services, at a certain price, to be sold in certain outlets, to be promoted through certain activities and communication channels, and supported by certain services. Mistakes in marketing implementation can destroy a brand at the most important time for consumers (Gelder, 2005 , p. 3). In the fourth stage, brand perception is to understand which valuations influence consumer perceptions of certain types of brands and then determine the potential of the brand among consumers in certain markets (Gelder, 2005, p. 3). The fifth stage, brand recognition is a way that distinguishes consumers between brands and competitive brands so that it is not just awareness (Gelder, 2005, p. 3). The last stage of consumer behavior is the behavior of consumers who value a brand so that they are happy to part with their money and are satisfied in the process (Gelder, 2005, p. 4). If in the case of taxation in Indonesia, certainly the achievement of tax-conscious taxpayer behavior.

\section{The Interaction Stimulant Factors on Social Media Instagram}

Dr. Mary Aiken believes that humans have always influenced and shaped by technology but there is no greater influence than the internet. Technology and the internet have changed the pattern of human 
interaction relationships. The internet gave birth to the era of social media where active users in Indonesia reached 130 million with high penetration reaching 49 percent (Pertiwi, 2018). And, the latest research results show the average android user spends time surfing on Instagram social media for 53 minutes (Ahl, 2018). Instagram is interpreted by Krieger, one of the founders, as an application for gadgets to take photos and process photos, a community that shares photos between one member and another and the whole world, a giant and medium sized gallery that creates a network of friends. As one of the results of technology, Instagram can make a very large contribution in business (Kasali, 2018, p. 42). In other words, through an Instagram account, the Directorate General of Taxes of the Republic of Indonesia can create a pattern of interaction relationships with taxpayers for equity, speed and service.

As a gallery, photos/videos uploaded on Instagram are real photos and animations. Real photos are synonyms of portraits which are literally images made with cameras and other photographic equipment (Rahardi, 2006, p. 83). While the animation or drawings according to KBBI are imitations of goods (people, animals, plants, etc.) made with pencil drawings and so on paper and so on. In the Bali Tourism Social Media Content Analysis research obtained components that encourage interaction from Instagram. These components are the type of photo/ image, type of caption, hashtag, number of followers, number of likes / love, and number of comments (Surijah et al., 2017, pp. 5-6). In a previous study on Analysis of Social Media Content in Bali Tourism by Edwin Adrianta Surijah, et al explained the photos uploaded, there are several content elements that will be used as determining factors, namely the type of photo/image, type of caption, hashtag, number of followers, number of likes/love, and number of comments. Types of photos / images consist of 1) animate - subject in frame that is a photo of a person posing; 2) animate - people in frame that is a photo containing people who are on the move or doing activities in the context of the photo; 3 ) nature/inimate 
which is a photograph of an object without people or individuals (Surijah et al., 2017, p. 6).

Caption or title or label given to uploaded photos which are classified into persuasive, descriptive and informative sentences. A persuasive caption is a call to action. Descriptive captions are sentences that contain only description of the contents of the image. Meanwhile, informative captions are sentences that provide information such as background or related facts (Surijah et al., 2017, p. 6).

One of most frequently and easily to use is hashtag feature in Instagram by the fence symbol (\#) accompanied by the desired keyword (Surijah et al., 2017, p. 10). The disadvantage of Hashtags is that the more using the same hashtag, the more likely the uploaded image is quickly buried by uploads from other users. But the advantages, if you use the same hashtag, it is more likely that more people will see the uploaded image (Surijah et al., 2017, p. 11).

\section{Research Methodology}

This research examines interaction stimulant factors through posting of the photo and text elements in the @ditjenpajakri. It has amounting to 504 posts during 2018 as of Desember 25, 2018. This research uses content analysis method which is a quantitative approach. This method help to find a description of the characteristics of the contents and draw inference from the contents (Eriyanto, 2015, p. 15). This study uses descriptive statistical techniques, namely content analysis to describe facts, symptoms or phenomena. This research is not intended to test certain hypotheses but describe descriptively aspects of the contents (Eriyanto, 2015, p. 15). 


\section{Results and Discussion}

\section{Types of Photos / Pictures on the @ditjenpajakri Account}

On Desember 25, 2018, 504 posts had been uploaded to the @ ditjenpajakri account consisting of 428 photos and 76 videos. At 428 photos uploaded 220 uploads are single photos and 208 uploads are multiphoto or slide uploads. While of the 76 video uploads almost all were single video uploads except the March 29, 2018 upload on Annual SPT reporting using EFiling by DPDRI Chair Oesman Sapta Oddang and MPR Chair Zulkifli Hasan. Specifically, upload 2018 is discussed in the form of photos with a single classification of $43.65 \%$, real $58.73 \%$ and not tagged for other accounts $58.73 \%$. The following are the total uploads for each of the components driving the @ditjenpajakri account interaction, as follows:

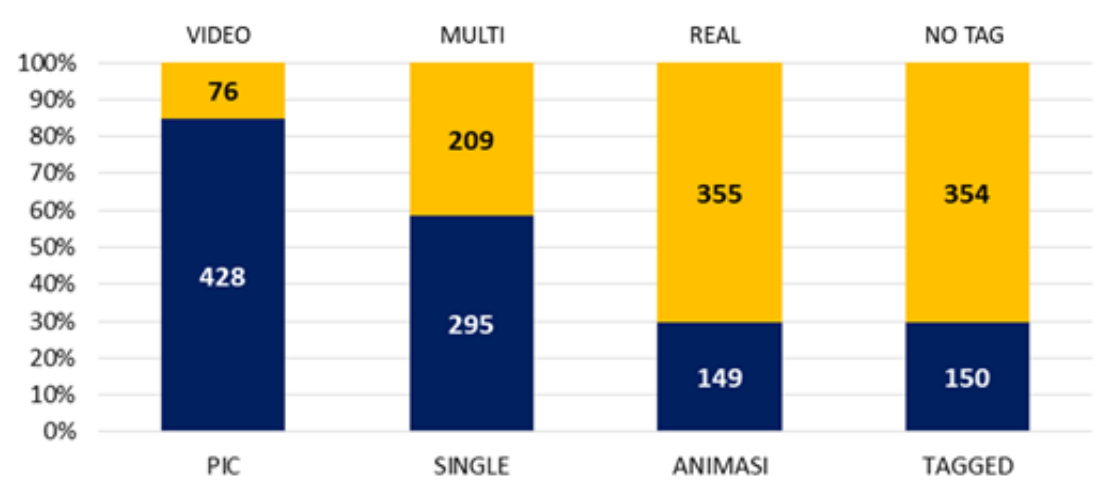

Graph 2: Total Uploads of Each Component Driving Account Interaction@Directorate General of Taxation (Source: @ditjenpajakri account, data processed)

Based on 150 posts tagged to other accounts, as of Desember 25, 2018, the@ditjenpajakri account has tagged as many as 135 other accounts. The top three most marked accounts are @jokowi 9 times, @ kemenkeuri11 times and@smindrawati 32 times. The three accounts are 
also accounts that are followed by the @ditjenpajakri account.

\section{Like and comment on @ditjenpajakri's account}

Account posting@ditjenpajakri 2018 received totaly 1,613,083 likes and 23,604 comments. Looking at these data, the @ditjenpajakri account received an average of 3,200 likes with the most number of likes of 47,510 in the upload on August 19, 2018 about congratulations and proud of the achievements of Defia Rosmaniar athlete Taekwondo Poomsae who won the first gold medal for Indonesia at the Asia Games. However, getting the smallest number of likes was 478 likes in the upload of information on the UMKM Final PPh tariff reduction on October 12, 2018. It was different in the comments component, because on average it was only 46.8 comments and around $8 \%$ of uploads did not get comments. However, there was a very crowded upload that reached the highest commentary of 1,856 comments, namely on the October 29, 2018 upload about the presence of the Minister of Finance at the Lion Air Crisis Center to assist the families of employees. Here are the total likes and comments on each component driving the interaction:

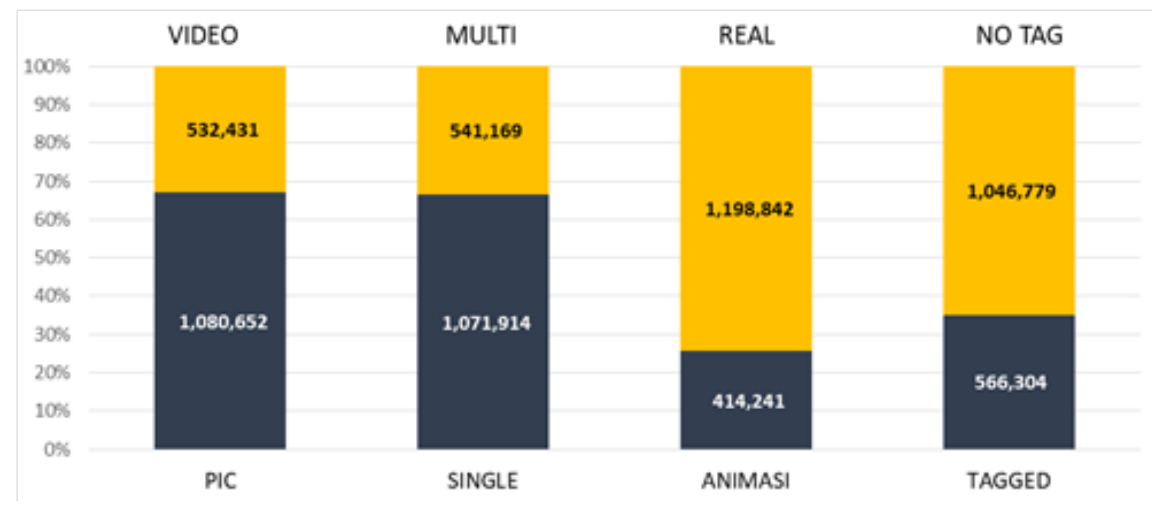

Graph 3: Total Like Each Component Drivers of Account Interaction @ ditjenpajakri (Source: @ditjenpajakri account, data processed) 


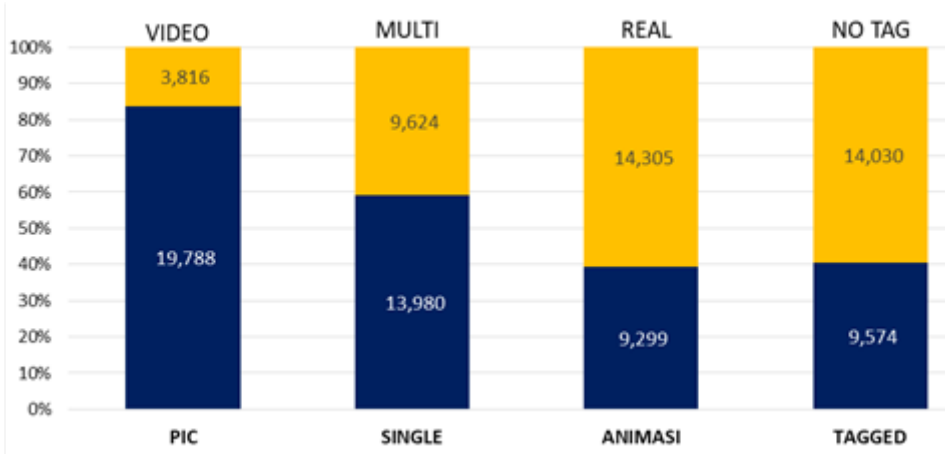

Graph 4: Total Comments for Each Component Driving Account Interaction@ditjenpajakri (Source: @ditjenpajakri account, data processed)

Then, the researchers tried to link uploading photos and videos that were shared with other components. This is done to find out whether netizens prefer uploads in what form. The following graphic photos and videos in the form of single-multi, real animation and using tags or not based on netizens like, as follows:

Table 1: Photos and Videos in Single-Multi Forms, Real Animations and Using Tags - Without Tags Based on Like Netizens in 2018. Source: @ ditjenpajakri account, data processed

\begin{tabular}{|c|c|c|c|c|c|c|c|c|}
\hline & \multicolumn{4}{|c|}{ LIKE } & \multicolumn{4}{|c|}{ KOMENTAR } \\
\hline & \multicolumn{2}{|c|}{ PIC } & \multicolumn{2}{|c|}{ VIDEO } & \multicolumn{2}{|c|}{ PIC } & \multicolumn{2}{|c|}{ VIDEO } \\
\hline & SINGLE & MULTI & SINGLE & MULTI & SINGLE & MULTI & SINGLE & MULTI \\
\hline TOTAL & 540,494 & 540,158 & 531,420 & 1,011 & 10,206 & 9,582 & 3,774 & 42 \\
\hline MEAN & 2,457 & 2,597 & 7,086 & 1,011 & 46 & 46 & 50 & 42 \\
\hline MAX & 47,510 & 44,789 & 26,953 & 1,011 & 1,319 & 1,856 & 1,350 & 42 \\
\hline \multirow[t]{2}{*}{ MIN } & 717 & 478 & 1,187 & 1,011 & - & - & - & 42 \\
\hline & ANIMASI & REAL & ANIMASI & REAL & ANIMASI & REAL & ANIMASI & REAL \\
\hline TOTAL & 258,667 & 821,985 & 155,574 & 376,857 & 8,260 & 11,528 & 1,039 & 2,777 \\
\hline MEAN & 1,960 & 2,777 & 9,151 & 6,387 & 63 & 39 & 61 & 47 \\
\hline MAX & 8,951 & 47,510 & 21,007 & 26,953 & 1,319 & 1,856 & 198 & 1,350 \\
\hline \multirow[t]{2}{*}{ MIN } & 717 & 478 & 1,331 & 1,011 & - & - & 14 & - \\
\hline & TAGGED & NO TAG & TAGGED & NO TAG & TAGGED & NO TAG & TAGGED & NO TAG \\
\hline TOTAL & 436,025 & 644,627 & 130,279 & 402,152 & 7,548 & 12,240 & 2,026 & 1,790 \\
\hline MEAN & 3,303 & 2,178 & 7,238 & 6,934 & 57 & 41 & 113 & 31 \\
\hline MAX & 47,510 & 17,701 & 16,502 & 26,953 & 1,856 & 1,319 & 1,350 & 198 \\
\hline MIN & 478 & 717 & 1,011 & 1,187 & - & - & - & - \\
\hline
\end{tabular}


Based on the data above, the @ditjenpajakri account has posted in the form of photos and videos that has reach an average of more than 500,000 likes. If you see the average likes between photos and videos it turns out that more netizens like videos in singles, animations and tagged. Whereas in the comments, in 2018 the @ditjenpajakri account received more comments on uploads in the form of photos than videos. However, when viewed on average the comments turned out to be the most superior are uploads in the form of single videos, animated photos and videos tagged to other accounts.

Type Caption on@ditjenpajakri Account

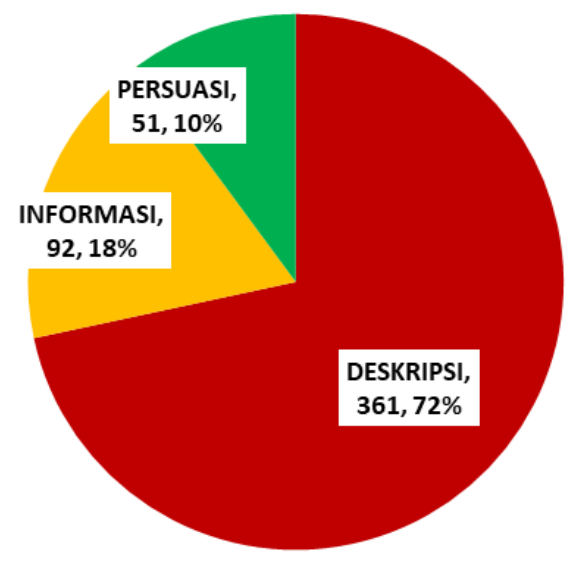

Graph 5: types of captions on the @ditjenpajakri account on uploads in 2018. (source: @ditjenpajakri account, data processed)

Seeing of the data, the caption from uploading of @ditjenpajakri account has not been widely used persuasively, in the description caption is still widely used. Why is persuasion caption important? It was mentioned earlier that Gelder revealed that brands need marketing. Meanwhile, persuasion is the essence of marketing communication by influencing the attitudes and ends of consumer behavior (Shimp, 2000, p. 227). Persuasion in an invitation or persuasion sentence may indeed not be optimized yet, 
but the caption description and information are expected to be able to increase the attitude both conigently, affective and conactively, especially the trust of taxpayers in Indonesian taxation.

\section{Hashtag on Account @ditjenpajakri}

The count of hashtags / hashtags (\#) on 504 uploads in 2018, there were 26 types of hashtags with a total of 686 hashtags. But there are 138 uploads that don't use Hashtags at all. The most widely used hashtags in 2018 are \#PajakKitaUntuKita, which totaled 137 times, then \#PawanPajak 82 times, \#LIVE 60 times, \# AsianGames2018 23 times, \#BikinBanggaIndonesia 19 times and \#SadarPajak only 18 times.

\section{Conclusion}

interaction stimulant factors in account @ditjenpajakri consist types of photos / images, number of likes / followers and followers / comments, types of captions, and hashtags. As many as 504 posts have been uploaded to @ditjenpajakri account which is dominated by $80 \%$ of the video. Even though when viewed on average the likes and comments given by netizens, the video turns out to get more attention. In other words, netizens appreciate video uploads more than photos. Caption is mostly used in the form of sentence description while persuasion sentence is still (persuasion/invitation) is still not widely used. The most Hashtag on account @ditjenpajakri is \#PajakKitaUntuKita 137 times. However, hashtag \#sadarpajak only done 7 times and \#generationtax tax is nothing.

The results of this study illustrate the characteristics of the @ ditjenpajakri account as an the brand of Indonesian's tax which can be used evaluation. Then, the results become the preparation material for the Indonesian Tax Directorate's brand to reach a tax-conscious generation. Therefore, the @ditjenpajakri account as a communication medium can be optimized in the purpose of interaction, maintaining good relationships and then increasing trust and awareness of paying taxes. The limitation 
of this research is that it still measures the driving force of the interaction of @ditjenpajakri accounts quanti- cally not yet explored qualitatively. So, the next research still needs qualitative analysis on the upload of @ ditjenpajakri account.

\section{Bilbliography}

Eriyanto. 2015. Analisis Isi: Pengantar Metodologi untuk Penelitian Ilmu Komunikasi dan Ilmu-ilmu Sosial Lainnya. Prenada Media.

Gelder, S. V. 2005. Global Brand Strategy: Unlocking Branding Potential Across Countries, Cultures \& Markets. Kogan Page Publishers.

$\mathrm{Hu}, \mathrm{Y} .$, Manikonda, L., \& Kambhampati, S. 2014. What we instagram: A first analysis of instagram photo content and user types, 595-598.

Kasali, R. 2018. The Great Shifting. Gramedia Pustaka Utama.

Quddus, G. G. (2018, Agustus 7). Rasio Pajak di Bawah Standar Bank Dunia, Sri Mulyani Malu. Diambil 14 November 2018, dari https:// ekonomi.kompas.com/read/2018/08/07/090400726/rasiopajak-di-bawah-standar-bank-dunia-sri-mulyani-malu

Rahardi, F. 2006. Panduan lengkap menulis artikel, feature dan esai: modul dasar pelatihan jurnalistik bagi pemula dilengkapi dengan aneka contoh tulisan. Kawan Pustaka.

Salleh, S., Hashim, N. H., \& Murphy, J. 2015. Instagram Marketing: A Content Analysis of Top Malaysian Restaurant Brands, 6, 5.

Shimp, T. A. 2000. Periklanan dan Promosi, edisi 5, jilid 1. Erlangga.

Surijah, E. A., Kirana, C. T., Wahyuni, N. P. J. D., Yudi, P. C., \& Astini, N. K. B. (2017). Membedah Instagram: Analisis Isi Media Sosial Pariwisata Bali. Intuisi : Jurnal Psikologi Ilmiah, 9(1), 1-17.

Internet

Afrianto, D. (2016, September 21). 7 Alasan Rendahnya Kesadaran Masyarakat Bayar Pajak: Okezone Economy. Diambil 15 November 2018, dari https://economy.okezone.com/ 
$\mathrm{read} / 2016 / 09 / 21 / 20 / 1495183 / 7$-alasan-rendahnya-kesadaranmasyarakat-bayar-pajak

ahl. (2018, Juli 11). Riset: Pengguna Android Habiskan Rata-Rata 53 Menit di Instagram. Diambil 27 Desember 2018, dari https://techno. okezone.com/read/2018/07/11/207/1920691/riset-penggunaandroid-habiskan-rata-rata-53-menit-di-instagram

HIDAYAT, A. A., ALI. (2017, Juli 26). 45 Juta Pengguna Instagram, Indonesia Pasar Terbesar di Asia. Diambil 14 Desember 2018, dari https://bisnis.tempo.co/read/894605/45-juta-penggunainstagram-indonesia-pasar-terbesar-di-asia

Pertiwi, W. K. (2018, Maret 1). Riset Ungkap Pola Pemakaian Medsos Orang Indonesia. Diambil 27 Desember 2018, dari https://tekno.kompas. com/read/2018/03/01/10340027/riset-ungkap-pola-pemakaianmedsos-orang-indonesia

Sembiring, L. J. (2017, Juni 21). Kesadaran Membayar Pajak Rendah, Tax Rasio RI Kalah dari Malaysia dan Thailand: Okezone Economy. Diambil 14 November 2018, dari https://economy.okezone.com/ $\mathrm{read} / 2017 / 06 / 21 / 20 / 1721979 /$ kesadaran-membayar-pajakrendah-tax-rasio-ri-kalah-dari-malaysia-dan-thailand 